\title{
Multiple sclerosis \\ - new therapeutic directions
}

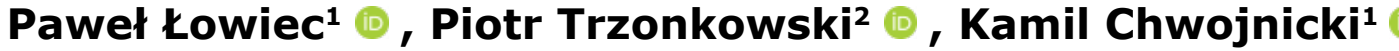

${ }^{1}$ Department of Adult Neurology, Medical University of Gdańsk, Poland

${ }^{2}$ Department of Medical Immunology, Medical University of Gdańsk, Poland

\begin{abstract}
Multiple sclerosis (MS) is a chronic inflammatory and neurodegenerative disease which affects the central nervous system. Currently, there are numerous disease-modifying therapies for this condition. Most of them address the inflammatory aspects of the disease and are most effective in the relapsing-remitting stages of multiple sclerosis. However, none of them can completely stop the progression of MS and they are usually associated with adverse effects. There is an ongoing search for novel approaches that involve different modes of action. Here, we discuss examples of new immunomodulating agents such as antigen-specific therapies, neuroprotectants, regenerative strategies and gut microbiota modification.

Keywords: multiple sclerosis $•$ neuroprotection $\bullet$ novel therapies $•$ remyelination $\bullet$ gut microbiome
\end{abstract}

\section{Citation}

Łowiec P, Trzonkowski P, Chwojnicki K. Multiple sclerosis - new therapeutic directions.

Eur J Transl Clin Med. 2019;2(1):7-22.

DOI: $10.31373 / \mathrm{ejtcm} / 109612$

\section{Introduction}

Multiple sclerosis (MS) is a chronic, autoimmune, demyelinating inflammatory and neurodegenerative disease that involves the central nervous system (CNS). It most commonly affects people between 20 and 40 years of age, predominantly women and it is a major cause of neurological disability among young adults. Most individuals with MS (85\%) experience relapses-remissions during which rapid neurological worsening is followed by subsequent resolution of the symptoms.
Unfortunately, after approximately 5-20 years the disease evolves into secondary-progressive phase, where the acute exacerbations are less frequent but there is a gradual neurological worsening overtime. A minority of patients develop a primary-progressive course of MS, with a constant increase in disability from the onset with no noticeable relapses [1].

MS has a multifactorial and complex pathogenesis with genetic and environmental factors involved [2-3]. The inflammation in CNS is driven by adaptive and innate immune system components [4]. Moreover, the-

Corresponding author:

Kamil Chwojnicki, Department of Adult Neurology, Medical University of Gdańsk, Poland

e-mail: kchwoj@gumed.edu.pl

No external funds.

Available online: www.ejtcm.gumed.edu.pl

Copyright $®$ Medical University of Gdańsk

This is Open Access article distributed under the terms of the Creative Commons Attribution-ShareAlike 4.0 International. 
re is a dysfunction of T-regulatory cells in people with MS. It is thought that peripheral failure of tolerance facilitates auto-reactive T-cell activation, possibly by an infectious agent through a mechanism of molecular mimicry. Although MOG, MBP, PLP and other molecules have been suggested, initiating target of the immune attack is still unknown. T-helper cells are shifted towards disease-promoting Th1 and Th17 populations and B-lymphocytes also take a part in MS pathology [56]. Destruction of myelin reveals new, previously sequestered neuroantigens, which become a target for the immune system, perpetuating continuous destruction in the CNS [7]. As the disease progresses there is less and less inflammatory activity. Patients still accumulate disability through gradual axonal loss due to neurodegeneration that dominates in the progressive phase of MS. Factors such as mitochondrial dysfunction, oxidative stress, intracellular ion imbalance, microglia activation may contribute to that process.

Currently, none of the available disease-modifying drugs (DMDs) arrest completely the disease or can be considered fully curative. Most of these therapies are immunosuppressive and turn down immune responses without appropriate specificity towards defined disease-associated autoantigens. Thus, novel therapies involve selective approaches that promise to affect only auto-reactive processes specific to MS [1]. This could not only enhance efficacy, but also reduce side effects. Many problems still persist in reestablishing immunotolerance such as route of administration of therapeutic agents, optimal dose and distribution to the CNS. Current options in progressive MS are limited because available therapies address mainly the inflammatory aspect of the disease. They do not concentrate on halting neurodegeneration nor do they aim to regenerate neural tissue that is already lost. Thus, there is an ongoing search for novel therapies. Here, some of the current strategies will be highlighted.

\section{Antigen specific approaches}

\section{Transderamal Myelin Antigens}

A promising approach is concentrated on induction of tolerance to specific auto-antigens by applying transdermal patches saturated with a mixture of myelin peptides: MOG 35-55 (myelin oligodendrocyte glycoprotein), MBP 85-99 (myelin basic protein) and PLP 139-151 (proteolipid protein) [8]. Patients with relapsing-remitting MS (RRMS) have been observed and compared to placebo. The treated individuals, have shown slower disability progression, less lesion accu- mulation and lower relapse rate [9]. Myelin peptides, administered at doses of $1 \mathrm{mg}$ and $10 \mathrm{mg}$ transdermally, have induced a specific population of dendritic cells in the skin and local lymph nodes and promoted generation of Tr1 regulatory T-cells. As a result, weakened myelin-related immune responses have been observed. Transdermal treatment has caused an increase in IL-10 with concomitant decrease in TGF-beta and IF$\mathrm{N}-\mathrm{y}$ secretion. Interestingly, the therapy did not affect the percentage of CD4+CD25+FoxP3+T-reg population [8]. Administration of transdermal myelin antigens proved to be safe with only mild local irritation of the skin reported [9].

\section{Tolerogenic Dendritic Cells}

Dendritic cells (DCs), not only process, present antigens and activate immune responses, but are also implied in tolerance induction. The main subpopulations of these cells are myeloid and plasmocytoid dendritic cells. Depending on the surrounding environment and maturation level they can be divided into immunogenic and tolerogenic. Tol-DCs are thought to induce tolerance via T-cells promoting their deletion, anergy or inducing a regulatory phenotype [10]. This knowledge has been translated into studies in animal model of MS called experimental autoimmune encephalitis (EAE). In these trials introduction of Tol-DCs coupled with myelin oligodendrocyte glycoprotein (MOG) has protected from induction or suppressed activity of the disease [11-13]. In one study Tol-DCs generated from RRMS patients and coupled with PLP induced selective hyporesponsiveness in autoreactive T-cells in-vitro [14]. Further trials are needed to asses feasibility of this approach in-vivo. Selective tuning of immune responses offers a lesser risk of adverse effects and perhaps greater efficacy. There are remaining questions about the best route of administration and selection of suitable myelin antigens in future studies that would apply tolerogenic dendritic cells [15].

\section{Autologous Myelin-Coupled PBMCs}

In ETIMS trial [16], induction of tolerance has been achieved through infusion of autologous peripheral blood mononuclear cells (PBMCs) coupled with selected myelin peptides in a group of RRMS and secondary progressive MS (SPMS) patients. Similar approach has been proven in experimental autoimmune encephalitis with amelioration of the disease in terms of occurrence and severity of relapses [17]. In the aforementioned human study, patients who have shown in-vitro responses to one of the seven epitopes of MOG, MBP and PLP have been enrolled. PBMCs were collected 
through leukapheresis and attached chemically to myelin peptides. Then, they were mixed with autologous plasma and administered intravenously to the patients. Participants were divided into two groups, one with low and the second- with high disease activity. They received escalating doses of the product. Reduction of specific T-cell responses to auto-antigens has been reported in the higher dose group. The proposed mode of action is thought to be induction of anergy to specific autoreactive T-cells, apoptosis of coupled cells and subsequent phagocytosis by APCs expressing IL-10 and PD-L1 [17-19]. Induction of regulatory cells has been indicated, but only a slight increase has been measured. Importantly, no elevation in Th1 and Th17 populations has occurred, with treatment being generally safe.

\section{DNA and Peptide-based vaccination}

An approach where a modified DNA encoding altered human myelin-basic protein (MBP) altered with less immunologically stimulating motifs has been explored as a therapeutic vaccine [20-21]. In this case, it was administered intramuscularly in a cohort of SPMS and RRMS patients. Reduction of newly forming lesions was observed, but with no substantial effect on clinical progression. In response to vaccination, less IFN-y secreting T-cells were produced and the levels of myelin-specific antibodies in the cerebrospinal fluid (CSF) decreased. Treatment was generally safe with no serious side effects. In another study, rather than DNA, introduction of TCR peptides from specific autoreactive T-cell clones has been used as a strategy [22-23]. They were administered either by intramuscular or intradermal route with addition of adjuvants to boost immunogenicity. The vaccine induced a subset of T-cells with subsequent reduction of responses to encephalitogens and secretion of IL-10 by these cells. Other proposed mechanism is related to an increased expression of FoxP3 in natural and inducible populations of T-regulatory cells [24]. Different approach used apitopes or short soluble peptides derived from naturally occurring MBP, which mimic processed epitopes [2526]. After intradermal injection, they are bound to MHC-class II receptors on immature dendritic cells and are thought to induce specific T-regs. Risk profile was low. The therapy was safe with local skin reactions observed in a group of patients. Another trial [27] used mannosylatedlyposomes (CD-206) to facilitate re-uptake of immunodominant MBP peptides by dendritic cells which in turn should promote tolerance [28].

Not all efforts in peptide vaccination proved to be safe. Fear of disease exacerbation must be taken into account as evidenced by clinical worsening in patients who received altered MBP peptide ligand delivered subcutaneously [29].

\section{Attenuated Autologous T-cells}

A different cell vaccination technique involved the irradiation of myelin-autoreactive T-cells selected to be specific towards MBP, collected from the peripheral blood of individuals with RRMS and SPMS [30]. After that, autologous cells were reintroduced to the patients. A reduction of clinical and radiological activity of the disease was observed. The probable mode of action was an induction of specific cytotoxic T-cells against irradiated auto-reactive clones, which results in their deletion and selective suppression of autoimmune responses. Treatment has been safe with no general immunosuppression. Other trials with attenuated auto-reactive T-cells have been performed [3133] with a wider repertoire of T-cells, auto-reactive not only to MBP. As in the first case, there were no serious adverse reactions.

\section{Regenerative therapies}

Prior therapeutic approaches targeted inflammatory processes that ultimately lead to demyelination and axonal loss. However, none of the above addressed possibilities of reversing the damage inflicted to the CNS during the course of MS. One avenue of research explores inhibition of molecules that contribute to myelin development suppression. LINGO-1 and AMIGO-3 are proteins which regulate neuroplasticity. LINGO-1 (Leucine-rich repeat and immunoglobulin-like domain-containing Nogo receptor-interacting protein 1) halts neurite outgrowth and mediates inhibitory effects on oligodendrocyte precursor maturation and therefore prevents axonal myelination. Other identified protein, AMIGO-3 (amphoterin-induced gene and open reading frame-3) exerts similar inhibitory effects as LINGO-1 [34]. Experimental blockage of LINGO-1 mediated signaling has shown benefits in animal models of CNS demyelination [35-36]. Human clinical studies gave mixed results. In the RENEW trial, Opicinumab (Li81 BIIB033) an anti-LINGO-1 antibody were used to treat acute optic neuritis. Some benefits were observed in patients assessed with multifocal visual-evoked potential (MF-VEP) measurement [37-38]. Furthermore, the antibody was tested in the SYNERGY study, where its safety profile and influence on disability was compared to interferon- $\beta$ therapy in SPMS and RRMS. Primary endpoint of the trial was not met. However, modest positive results with good risk profile were observed in intermediate dose subgroups [39-40].

Limited results from above studies could be explained by other mechanisms compensating for the loss of function by LINGO-1, therefore other therapeutic 
targets are sought [34]. Another discovery are natural antibodies (NAbs) directed towards CNS antigens and their remyelination-promoting subgroup [41-42]. One of them, rHIgM22 or recombinant human monoclonal IgM antibody-22, was used in EAE with positive effect on lesion load reduction and remyelination. Studies have shown that this antibody crosses the blood-brain barrier and exerts its effects without immunomodulation. It activates a signaling complex on oligodendrocyte precursor cells promoting their survival [43]. Presently, there are ongoing trials in $\mathrm{MS}$, demonstrating its safe risk profile [44-45]. Other candidate for CNS repair is rHIgM12, reactive towards gangliosides and polisialic acid on neuronal surface, which promotes axonal growth [46]. Well known hormone, erythropoietin, induces remyelination and neuronal growth beyond its primary effects [47]. Although clinical benefit in small studies has been reported, larger trials have not proven efficacy in progressive MS [48-50].

Another approach is associated with multiple sclerosis-associated retrovirus (MSRV), which is a latent, endogenous virus, integrated into the genome. It can be reactivated in the course of EBV infection and the envelope protein (MSRV-env) has been found in CNS lesions of MS patients. As a Toll-like receptor-4 an agonist, MSRV-env has been shown to have proinflammatory properties, preventing remyelination by inhibition of oligodendrocyte maturation [51]. GNbAC1 is a monoclonal antibody engineered to bind the envelope protein which indirectly suppresses neuroinflammation and favors myelin deposition. CHANGE-MS trial in RRMS [52] supports GNbAC1 effects on remyelination [53-55]. Small molecules could also have similar capabilities. Domperidone, a dopamine receptor antagonist, is being tested in SPMS patients as prolactin released secondary to dopamine blockade, could improve remyelination [56-58].

Novel monoclonal antibodies targeting the immune system

\section{Immune cell targeting monoclonal antibodies}

Rituximab is not officially approved for the treatment of MS, but this anti-CD20 chimeric monoclonal antibody is used off-label and has shown efficacy in remitting-relapsing forms of the disease. It reduces the annual relapse rate (ARR) and risk of enlarging T2 MRI lesions in comparison to placebo as shown in HERMES trial. Its mechanism of action is similar to ocrelizumab and it is thought to be depletion of circulating B-cells and CD20-bearing T-cells.
Ocrelizumab has been approved in 2017 for the treatment of MS. This anti-CD20 monoclonal antibody is a breakthrough, because it is the first type of treatment that has been proven to show benefit in individuals with the primary progressive form of MS.

The success of monoclonal antibodies such as ocrelizumab and rituximab has led to further search for drugs with similar pharmacodynamics. Ofatumumab, an anti-CD20 humanized antibody, has been used in the treatment of chronic lymphocytic leukemia and rheumatoid arthritis [59-60]. As compared to rituximab, it binds to a different epitope resulting in a more pronounced complement-dependent cytotoxicity due to slower dissociation from the targeted antigen. As a result, profound $\mathrm{B}$-cell depletion is noted. In phase II trial, ofatumumab has been administered intravenously to RRMS patients, with no increased risk of severe infections [61]. Ofatumumab has shown efficacy in reducing MRI markers of disease activity. Another placebo-controlled trial in RRMS patients explored a subcutaneous route of administration with good tolerance and comparable neuroimaging results [62].

Inebilizumab (MEDI-551) is a monoclonal antibody targeting CD19 receptor. It causes a rapid B-cell depletion similarly to the therapies directed against CD20(+) cells and immunologically translates to comparable effects. RRMS patients in phase I study, had slower lesion accumulation and acceptable risk [63]. BAFF or B-cell activating factor is a protein found both on B-lymphocyte membranes and in an unbound form. Its main function is a promotion of B-cell activation and survival. Located mainly on mature B-cells, BAFF is a target for tabalumab. Tested in patients with SLE and rheumatoid arthritis, it has shown effects on biological markers but with no clinical benefit. Acknowledging the role of B-cell mediated pathology in MS, tabalumab has been investigated as an option for patients with RRMS in a trial focused on safety and radiological activity markers, although with no reduction in new gadolinium-enhancing lesion formation [64].

\section{Cytokine targeting monoclonal antibodies}

The role of IL-17 and IL-12 has been implied in the pathophysiology of MS. T-lymphocytes that undergo differentiation to a Th17-phenotype are linked to neuroinflammation as their concentration correlates with disease severity in EAE. IL-17 activates microglia, macrophages and astrocytes, which secrete cytokines such as IL-6, TNF-a, IL-1 which in turn increase blood-brain barrier permeability and recruit more immune cells into the CNS. Enhanced myelin destruction and axonal loss occurs as a result [65]. IL-12 secreted by APCs in the CNS activates macrophages, B-cells, Th1 
cells and promotes inflammation. As in the periphery, this cytokine together with IL-23 differentiate naive T-cells into a Th17-subtype.

Ustekinumab is a monoclonal antibody targeted against the p40 subunit of IL-23 and IL-12 cytokines [66]. Studies using the EAE model have shown reduction in disease severity, however its efficacy has not been supported in human trials [67-69]. This discrepancy could be explained by low fraction of antibodies crossing the BBB, non-dependence from IL-23 signaling and disease compartmentalization to the CNS in the later stages of MS [70].

Secunikumab, a monoclonal antibody specific to IL-17A, aims to block the effects of this cytokine. Selective targeting of this interleukin is more beneficial than suppression of Th17 cells, because IL-17 can be secreted independently by $\delta \gamma T$ cells, astrocytes and oligodendrocytes in the CNS. There is the evidence that it could reduce radiological activity in patients with RRMS [71]. Risk of adverse effects has been acceptable with higher incidence of infections.

Tocilizumab approved for the treatment of resistant rheumatoid arthritis, is an antibody directed against IL-6, which promotes differentiation of naive T-cells towards Th17 subtype [72]. Blockage of this signaling has prevented the development of EAE. Unfortunately, tocilizumab has been associated with cases of new-onset $\mathrm{MS}$ in patients receiving the antibody for other indications, which raises concerns about its safety profile [73].

Aside from its proliferative properties, GM-CSF activates and recruits myeloid cells to the CNS during neuroinflammation and promotes their maturation [74]. MOR103 is a monoclonal antibody that interferes with GM-CSF on coupling to its receptor. As subsets of B-cells produce GM-CSF and contribute to MS pathology [75], MOR103 has become a potential treatment option in MS and recent trials have shown good tolerance of this drug [76].

\section{Neuroprotectants}

\section{Ion-channel blockers}

Experimental evidence has shown that the accumulation of sodium ions may lead to an increased intracellular calcium concentration. This activates signaling that can cause cell death. This mechanism can be referred to the neuronal loss seen in MS patients [7778]. Ion channel blockade can reduce influx of sodium and thus lead to neuroprotection. Many antiepileptic drugs act as sodium-channel blockers and are being explored as a treatment in MS. Lamotrigine has been investigated in trials as a neuroprotectant with mixed results [79]. One study has not shown efficacy in reducing serum neurofilament concentrations in patients receiving lamotrigine, although subgroup analysis has suggested some benefit [80]. Phenytoin administered in acute optic neuritis has had a positive effect on retinal nerve fiber thickness measured using OCT [81]. Another trial using the EAE model supports the efficacy of oxcarbamazepine [82]. It has been studied in SPMS patients in order to explore its neuroprotective properties (NCT02104661). Riluzole, a tetradotoxin-gated sodium channel blocker, is being tested in hope that it could prevent neurodegeneration in MS [83-84]. Further developments are ongoing as other agents share similar mode of action [85]. Amiloride, an acid-sensing sodium ion channel blocker, has been explored as a treatment in SPMS [83]. However, results in optic neuritis have been unsatisfactory [86].

\section{Inhibitors of microglia activation}

Microglial cells as a part of the innate immune system are thought to participate in destructive processes in the course of MS. Fluoxetine, aside from its antidepressant activity, also acts as a blocker of microglial-mediated inflammation. Furthermore, it has other beneficial effects such as up-regulating the expression of BDNF [87-88].

Laquinimod, which has undergone phase III trials, has not shown slower disability progression in lower doses (CONCERTO trial) in RRMS patients. Moreover, higher doses have been linked to unacceptable risk of cardiovascular events. Clinical studies in PPMS gave unsatisfactory results [89-90]. Pretreatment as well as administration in developed EAE caused reduced demyelination. Spinal cords and optic nerves of treated mice were infiltrated by phagocytes to a lesser extent in laquinimod treated groups. Human immune cells treated in-vitro also displayed decreased activation, thus suggesting the role of this mechanism in neurodegeneration [91-93].

Minocycline, an oral antibiotic from the tetracycline family, beyond antimicrobial activity, also exerts anti-inflammatory effects. It inhibits NMDA-mediated microglia activation in-vitro and it also promotes alternate anti-inflammatory differentiation of these cells in animal models of post-stroke neuroinflammation [9495]. These effects could also be explored in MS and one study has shown a reduced risk of transformation from CIS to MS [96].

Ibudilast, an phosphodiesterase inhibitor, is a small molecule that crosses the blood-brain barrier. It acts as a neuroprotectant by inhibiting microglia activation 
and antagonism of macrophage-migration inhibitory factor. Furthermore, it also induces neurotrophin secretion [97-98]. In phase II trial ibudilast has exhibited efficacy in slowing down brain atrophy in patients with progressive MS [99].

\section{Antioxidants and agents improving mitochondrial function}

Disruption of energy production and dysfunction of mitochondria has been already implied as a contributing factor for neurodegeneration which takes place in MS. Increased demand for ATP in demyelinated axons with insufficient production of ATP by mitochondria can lead to intracellular sodium accumulation and secondary influx of calcium ions that promotes cell death [100-102]. Biotin is essential for energy homeostasis as it functions as a co-factor for essential enzymes catalysing carboxylation. These are involved in lipid synthesis, amino acid metabolism and Krebs cycle. Administration of high oral doses has slowed and, in some cases, reversed disability progression in patients with progressive MS. Beneficial effect on visual acuity has been reported in MS patients with progressive optic neuropathy. It probably promotes remyelination and mitochondrial energy production [103-105]. Biotin-dependent acetyl-CoA carboxylase catalyses the synthesis of malonyl-CoA, a substrate for production of fatty acids and thus, promotes myelin deposition. Furthermore, it may provide substrates for the Krebs cycle and raise levels of intracellular ATP.

Idebenone, an ubiquinone analogue, also functions as an electron carrier in oxidative phosphorylation. Trials with this agent gave positive but disputable results in Leber's hereditary optic neuropathy [106] and Friedreich's ataxia, genetic diseases where mitochondrial dysfunction has been reported [107-108]. The antioxidant has been explored as a neuroprotectant in $E A E$, although recent studies have yielded unfavorable results. Nevertheless, idebenone has been investigated as a treatment for MS [109].

Another free radical scavenger, MitoQ consists of triphentylphophonium lipophilic cation attached to an alkyl chain linked with ubiquinone that enables it to be efficiently up-taken by mitochondria. It exerts its antioxidative effects by aiding mitochondrial function [110]. Administration has been protective against neuroinflammation and axonal degeneration in mice with induced EAE.

Alpha-lipoic acid, a natural molecule, has also potent antioxidative effects [111]. This endogenous molecule exerts neuroprotection via regeneration of glutathione pool, neutralization of free radicals and aids oxidative phosphorylation as a co-factor of pyruvate dehydroge- nase. Interestingly, it also inhibits leukocyte migration to the CNS. Alpha-lipoic acid has reduced MMP-9 and sl-CAM concentrations with positive effects on blood-brain barrier integrity and reduction of brain atrophy in a small cohort of SPMS patients [112-113].

\section{Neuroprotective agents with other modes of action}

Simvastatin, the statin noted for its protective effects on vasculature, has pleiotropic effects aside from suppression of cholesterol synthesis. It is also known for its immunomodulatory effects [114]. It has been investigated in SPMS as a disease-modifying drug in MS-STAT study. Improvement on the quality of life and cognition in patients receiving high-dose simvastatin has been reported and the rate of brain atrophy has been reduced [115-116]. These neuroprotective effects could be explained by a combination of positive effects on cerebral blood flow and anti-oxidative properties [117-118]. Further trials are needed to assess feasibility of simvastatin in MS.

Siponimod, closely related to fingolimod, is another immunomodulatory agent. It has a similar mode of action as it affects recirculation of lymphocytes from the lymph nodes. It improves over fingolimod as it is more selective towards S1P and S5P receptors. It has been shown to slow disability progression. Siponimod administration resulted in a reduction of brain atrophy in individuals with SPMS suggesting neuroprotective effects exerted by modulation of S1P and S5P receptors that may mediate brain cell survival. Adverse reactions are similar to fingolimod [119-120].

The role of glycogen synthase kinase-3 (GSK-3) is suggested in immune response regulation [121]. Lithium, a treatment for bi-polar disorder, suppresses the function of the enzyme and has caused prevention of EAE onset and disease amelioration [122]. A trial in progressive MS has been performed to study effects on brain atrophy and evaluate lithium's neuroprotective effects [123].

\section{Gut microbiome modification}

A complex community of microorganisms that inhabit the gastrointestinal tract is often referred to as the gut microbiome. Its influence on the nervous system has been more highlighted recently as it exerts its effects through immunological, endocrine and direct neural mechanisms [124]. The metabolites produced by intestinal bacteria such as short-chain fatty acids (SCFAs), sustain blood-brain barrier integrity, induce T-reg populations and regulate function of microglia in 
the CNS. Polisaccharide-A, a metabolite of Bacteroides fragilis, has been reported as an immunomodulatory factor. Furthermore, stress-mediated hypothalamic-pituitary axis activation can lead to changes in intestinal barrier permeability and dysbiosis through actions of glucocorticosteroids and catecholamines. Involvement of neural pathways between the digestive tract and the CNS is important. Bacteria in the gut may interact with afferent neural fibers by producing neurotransmiters and directly stimulate them with their molecular patterns. In addition, stimulation of efferent signaling nerves can regulate immune cell activity [125]. The role of this gut-brain axis has been implied in pathophysiology of psychiatric and neurological disorders such as MS [126].

Immunomodulatory effects caused by microbiome modification either by antibiotic treatment or probiotics can be supported by evidence from animal models [127-129]. In one study, the incidence of EAE was higher in genetically prone mice with gut microbiome transplanted from MS affected subjects [130]. There are also hints that people with MS have a distinct composition of gut flora [131]. Moreover, besides blood-brain barrier, the intestinal barrier is also disrupted in many patients with MS and it may contribute to pathology of the disease. Gut flora can affect bile acid composition and vice-versa. Thus, strategies to modify the gut microbiome have been formulated. Trials in EAE in which probiotics were used have shown efficacy [132]. There is a possibility that such microbiological interventions could be translated to patients with MS as there are results from human studies that support such approaches. For example, there are ongoing trials with fecal microbial transplantation (FMT) [133-135]. Therapeutical infestation with helminths has been also explored, because parasites are been known to skew immune response towards Th2 subtype, thus in effect ameliorating neuroinflammation [136-138].

\section{Conclusions}

Currently there is a variety of treatments available for patients with multiple sclerosis and this number is rising. They can be divided into symptomatic drugs (used in the setting of a relapse, e.g. glucocorticoids and IVIG) and disease-modifying drugs (DMD) that aim to influence long-term progression of the disease. None of aforementioned therapies are fully curative and most of them affect relapsing-remitting forms of the disease. Search for more specific therapies is ongoing that either try to reestablish self-tolerance, concentrate on regeneration and neuroprotection or modulate innate immune responses that are prominent in later stages of the disease and therefore promise a safer and hopefully more effective treatment in the future.

\section{Conflicts of interest}

None.

\section{References}

1. Weinshenker BG. The natural history of multiple sclerosis. Neurol Clin [Internet]. 1995;13(1):119-46. Available from: http://search.ebscohost.com/login.aspx?direct=true \&db=mdc\&AN=7739500\&lang=pl\&site=eds-live

2. The International Multiple Sclerosis Genetics Consortium \& The Wellcome Trust Case Control Consortium, Sawcer $S$, Hellenthal G, Pirinen M, Spencer CCA, Patsopoulos NA, et al. Genetic risk and a primary role for cell-mediated immune mechanisms in multiple sclerosis. Nature [Internet]. 2011;476:214. Available from: https://doi.org/10.1038/nature10251

3. Correale J, Gaitán MI. Multiple sclerosis and environmental factors: the role of vitamin D, parasites, and Epstein-Barr virus infection. Acta Neurol Scand [Internet]. 2015;132:46-55. Available from: http://doi.wiley.com/10.1111/ane.12431

4. Yadav SK, Mindur JE, Ito K, Dhib-Jalbut S. Advances in the immunopathogenesis of multiple sclerosis. Curr Opin Neurol [Internet]. 2015;28(3):206-19. Available from: http://content.wkhealth.com/linkback/openurl?sid=WKPTLP:landingpag e\&an=00019052-201506000-00002

5. Zhang Q, Vignali DAA. Co-stimulatory and Co-inhibitory Pathways in Autoimmunity. Immunity [Internet]. 2016;44(5):103451. Available from: https://linkinghub.elsevier.com/retrieve/pii/S1074761316301467

6. Claes N, Fraussen J, Stinissen P, Hupperts R, Somers V. B Cells Are Multifunctional Players in Multiple Sclerosis Pathogenesis: Insights from Therapeutic Interventions. Front Immunol [Internet]. 2015;6:642. Available from: http://journal. frontiersin.org/Article/10.3389/fimmu.2015.00642/abstract

7. Riedhammer C, Weissert R. Antigen Presentation, Autoantigens, and Immune Regulation in Multiple Sclerosis and Other Autoimmune Diseases. Front Immunol [Internet]. 2015;6:322. Available from: http://journal.frontiersin.org/Arti- 
8. Juryńczyk M, Walczak A, Jurewicz A, Jesionek-Kupnicka D, Szczepanik M, Selmaj K. Immune regulation of multiple sclerosis by transdermally applied myelin peptides. Ann Neurol [Internet]. 2010;68(5):593-601. Available from: http://doi. wiley.com/10.1002/ana.22219

9. Walczak A, Siger M, Ciach A, Szczepanik M, Selmaj K. Transdermal Application of Myelin Peptides in Multiple Sclerosis Treatment. JAMA Neurol [Internet]. 2013;70(9):1105. Available from: http://archneur.jamanetwork.com/article.aspx?doi=10.1001/jamaneurol.2013.3022

10. Flórez-Grau G, Zubizarreta I, Cabezón R, Villoslada P, Benitez-Ribas D. Tolerogenic Dendritic Cells as a Promising Antigen-Specific Therapy in the Treatment of Multiple Sclerosis and Neuromyelitis Optica From Preclinical to Clinical Trials. Front Immunol [Internet]. 2018;9. Available from: https://www.frontiersin.org/article/10.3389/fimmu.2018.01169/full

11. Papenfuss TL, Powell ND, McClain MA, Bedarf A, Singh A, Gienapp IE, et al. Estriol generates tolerogenic dendritic cells in vivo that protect against autoimmunity. J Immunol. 2011;186(6):3346-55.

12. Mansilla MJ, Sellès-Moreno C, Fàbregas-Puig S, Amoedo J, Navarro-Barriuso J, Teniente-Serra A, et al. Beneficial effect of tolerogenic dendritic cells pulsed with MOG autoantigen in experimental autoimmune encephalomyelitis. CNS Neurosci Ther. 2015;21(3):222-30.

13. Xie Z-X, Zhang H-L, Wu X-J, Zhu J, Ma D-H, Jin T. Role of the Immunogenic and Tolerogenic Subsets of Dendritic Cells in Multiple Sclerosis. Mediators Inflamm [Internet]. 2015;2015:1-20. Available from: http://www.hindawi.com/iournals/ $\mathrm{mi} / 2015 / 513295 /$

14. Raïch-Regué D, Grau-López L, Naranjo-Gómez M, Ramo-Tello C, Pujol-Borrell R, Martínez-Cáceres E, et al. Stable antigen-specific T-cell hyporesponsiveness induced by tolerogenic dendritic cells from multiple sclerosis patients. Eur J Immunol [Internet]. 2012;42(3):771-82. Available from: http://doi.wiley.com/10.1002/eji.201141835

15. Gross CC, Jonuleit $\mathrm{H}$, Wiendl $\mathrm{H}$. Fulfilling the dream: tolerogenic dendritic cells to treat multiple sclerosis. Eur J Immunol [Internet]. 2012;42(3):569-72. Available from: http://doi.wiley.com/10.1002/eji.201242402

16. Lutterotti A, Yousef S, Sputtek A, Sturner KH, Stellmann J-P, Breiden P, et al. Antigen-Specific Tolerance by Autologous Myelin Peptide-Coupled Cells: A Phase 1 Trial in Multiple Sclerosis. Sci Transl Med [Internet]. 2013;5(188):188ra75-188ra75. Available from: http://stm.sciencemag.org/cgi/doi/10.1126/scitranslmed.3006168

17. Turley DM, Miller SD. Peripheral Tolerance Induction Using Ethylenecarbodiimide-Fixed APCs Uses both Direct and Indirect Mechanisms of Antigen Presentation for Prevention of Experimental Autoimmune Encephalomyelitis. J Immunol [Internet]. 2007;178(4):2212-20. Available from: http://www.jimmunol.org/cgi/doi/10.4049/iimmunol.178.4.2212

18. Jenkins MK. Antigen presentation by chemically modified splenocytes induces antigen- specific $T$ cell unresponsiveness in vitro and in vivo. J Exp Med [Internet]. 1987;165(2):302-19. Available from: http://www.jem.org/cgi/doi/10.1084/ jem.165.2.302

19. Getts DR, Turley DM, Smith CE, Harp CT, McCarthy D, Feeney EM, et al. Tolerance Induced by Apoptotic Antigen-Coupled Leukocytes Is Induced by PD-L1+ and IL-10-Producing Splenic Macrophages and Maintained by T Regulatory Cells. J Immunol [Internet]. 2011;187(5):2405-17. Available from: http://www.jimmunol.org/cgi/doi/10.4049/jimmunol.1004175

20. Garren H, Robinson WH, Krasulová E, Havrdová E, Nadj C, Selmaj K, et al. Phase 2 trial of a DNA vaccine encoding myelin basic protein for multiple sclerosis. Ann Neurol [Internet]. 2008;63(5):611-20. Available from: http://doi.wiley. com/10.1002/ana.21370

21. Bar-Or A, Vollmer T, Antel J, Arnold DL, Bodner CA, Campagnolo D, et al. Induction of Antigen-Specific Tolerance in Multiple Sclerosis After Immunization With DNA Encoding Myelin Basic Protein in a Randomized, Placebo-Controlled Phase 1/2 Trial. Arch Neurol [Internet]. 2007;64(10):1407. Available from: http://archneur.jamanetwork.com/article.aspx?doi=10.1001/archneur.64.10.nct70002

22. Vandenbark AA, Chou YK, Whitham R, Mass M, Buenafe A, Liefeld D, et al. Treatment of multiple sclerosis with T-cell receptor peptides: Results of a double-blind pilot trial. Nat Med [Internet]. 1996;2(10):1109-15. Available from: http:// www.nature.com/articles/nm1096-1109

23. Vandenbark AA, Culbertson NE, Bartholomew RM, Huan J, Agotsch M, LaTocha D, et al. Therapeutic vaccination with a trivalent T-cell receptor (TCR) peptide vaccine restores deficient FoxP3 expression and TCR recognition in subjects with multiple sclerosis. Immunology [Internet]. 2008;123(1):66-78. Available from: http://doi.wiley.com/10.1111/i.13652567.2007.02703.x

24. Vandenbark A. TCR Peptide Vaccination in Multiple Sclerosis: Boosting a Deficient Natural Regulatory Network that may Involve TCR-Specific CD4+CD25+ Treg Cells. Curr Drug Target -Inflammation Allergy [Internet]. 2005;4(2):217-29. Available from: http://www.eurekaselect.com/openurl/content.php?genre=article\&issn=1568-010X\&volume=4\&is$\underline{\text { sue }=2 \& \text { spage }=217}$ 
25. Streeter HB, Rigden R, Martin KF, Scolding NJ, Wraith DC. Preclinical development and first-in-human study of ATXMS-1467 for immunotherapy of MS. Neurol - Neuroimmunol Neuroinflammation [Internet]. 2015;2(3):e93. Available from: http://nn.neurology.org/lookup/doi/10.1212/NXI.0000000000000093

26. Chataway J, Martin K, Barrell K, Sharrack B, Stolt P, Wraith DC. Effects of ATX-MS-1467 immunotherapy over 16 weeks in relapsing multiple sclerosis. Neurology [Internet]. 2018;90(11):e955-62. Available from: http://www.neurology.org/ lookup/doi/10.1212/WNL.0000000000005118

27. Belogurov A, Zakharov K, Lomakin Y, Surkov K, Avtushenko S, Kruglyakov P, et al. CD206-Targeted Liposomal Myelin Basic Protein Peptides in Patients with Multiple Sclerosis Resistant to First-Line Disease-Modifying Therapies: A First-in-Human, Proof-of-Concept Dose-Escalation Study. Neurotherapeutics [Internet]. 2016;13(4):895-904. Available from: http://link. springer.com/10.1007/s13311-016-0448-0

28. Belogurov AA, Stepanov A V., Smirnov I V., Melamed D, Bacon A, Mamedov AE, et al. Liposome-encapsulated peptides protect against experimental allergic encephalitis. FASEB J [Internet]. 2013;27(1):222-31. Available from: http://www. fasebi.org/doi/10.1096/fi.12-213975

29. Bielekova B, Goodwin B, Richert N, Cortese I, Kondo T, Afshar G, et al. Encephalitogenic potential of the myelin basic protein peptide (amino acids 83-99) in multiple sclerosis: Results of a phase II clinical trial with an altered peptide ligand. Nat Med [Internet]. 2000;6(10):1167-75. Available from: http://www.nature.com/articles/nm1000 1167

30. Zhang JZ, Rivera VM, Tejada-Simon M V., Yang D, Hong J, Li S, et al. T cell vaccination in multiple sclerosis: results of a preliminary study. J Neurol [Internet]. 2002;249(2):212-8. Available from: http://link.springer.com/10.1007/PL00007867

31. Karussis D, Shor H, Yachnin J, Lanxner N, Amiel M, Baruch K, et al. T Cell Vaccination Benefits Relapsing Progressive Multiple Sclerosis Patients: A Randomized, Double-Blind Clinical Trial. Basso AS, editor. PLoS One [Internet]. 2012;7(12):e50478. Available from: https://dx.plos.org/10.1371/journal.pone.0050478

32. Van der AA A, Hellings N, Medaer R, Gelin G, Palmers $Y$, Raus J, et al. T cell vaccination in multiple sclerosis patients with autologous CSF-derived activated T cells: results from a pilot study. Clin Exp Immunol [Internet]. 2003;131(1):155-68. Available from: http://doi.wiley.com/10.1046/j.1365-2249.2003.02019.x

33. Loftus B, Newsom B, Montgomery M, Von Gynz-Rekowski K, Riser M, Inman S, et al. Autologous attenuated T-cell vaccine (Tovaxin ${ }^{\circledR}$ ) dose escalation in multiple sclerosis relapsing-remitting and secondary progressive patients nonresponsive to approved immunomodulatory therapies. Clin Immunol [Internet]. 2009 May;131(2):202-15. Available from: https:// linkinghub.elsevier.com/retrieve/pii/S1521661609000072

34. Foale S, Berry M, Logan A, Fulton D, Ahmed Z. LINGO-1 and AMIGO3, potential therapeutic targets for neurological and dysmyelinating disorders? Neural Regen Res [Internet]. 2017;12(8):1247. Available from: http://www.nrronline.org/text. asp?2017/12/8/1247/213538

35. Mi S, Hu B, Hahm K, Luo Y, Kam Hui ES, Yuan Q, et al. LINGO-1 antagonist promotes spinal cord remyelination and axonal integrity in MOG-induced experimental autoimmune encephalomyelitis. Nat Med [Internet]. 2007;13(10):1228-33. Available from: http://www.nature.com/articles/nm1664

36. Sun J-J, Ren Q-G, Xu L, Zhang Z-J. LINGO-1 antibody ameliorates myelin impairment and spatial memory deficits in experimental autoimmune encephalomyelitis mice. Sci Rep [Internet]. 2015;5(1):14235. Available from: http://www.nature. com/articles/srep14235

37. Klistorner A, Chai Y, Leocani L, Albrecht P, Aktas O, Butzkueven H, et al. Assessment of Opicinumab in Acute Optic Neuritis Using Multifocal Visual Evoked Potential. CNS Drugs [Internet]. 2018;32(12):1159-71. Available from: http://link.springer.com/10.1007/s40263-018-0575-8

38. Cadavid D, Balcer L, Galetta S, Aktas O, Ziemssen T, Vanopdenbosch L, et al. Safety and efficacy of opicinumab in acute optic neuritis (RENEW): a randomised, placebo-controlled, phase 2 trial. Lancet Neurol [Internet]. 2017;16(3):189-99. Available from: https://linkinghub.elsevier.com/retrieve/pii/S1474442216303775

39. Mellion M, Edwards KR, Hupperts R, Drulović J, Montalban X, Hartung H-P, et al. Efficacy Results from the Phase 2b SYNERGY Study: Treatment of Disabling Multiple Sclerosis with the Anti-LINGO-1 Monoclonal Antibody Opicinumab (S33.004). Neurology [Internet]. 2017;88(16 Supplement):S33.004. Available from: http://n.neurology.org/content/88/16 Supplement/S33.004.abstract

40. McCroskery P, Selmaj K, Fernandez O, Grimaldi LME, Silber E, Pardo G, et al. Safety and Tolerability of Opicinumab in Relapsing Multiple Sclerosis: the Phase 2b SYNERGY Trial (P5.369). Neurology [Internet]. 2017;88(16 Supplement):P5.369. Available from: http://n.neurology.org/content/88/16 Supplement/P5.369.abstract

41. Bieber AJ, Warrington A, Asakura K, Ciric B, Kaveri S V, Pease LR, et al. Human antibodies accelerate the rate of remyelination following lysolecithin-induced demyelination in mice. Glia [Internet]. 2002;37(3):241-9. Available from: http:// www.ncbi.nlm.nih.gov/pubmed/11857682 
42. Warrington AE, Bieber AJ, Ciric B, Pease LR, Van Keulen V, Rodriguez M. A recombinant human IgM promotes myelin repair after a single, very low dose. J Neurosci Res [Internet]. 2007;85(5):967-76. Available from: http://doi.wiley. com/10.1002/inr.21217

43. Watzlawik J, Holicky E, Edberg DD, Marks DL, Warrington AE, Wright BR, et al. Human remyelination promoting antibody inhibits apoptotic signaling and differentiation through Lyn kinase in primary rat oligodendrocytes. Glia [Internet]. 2010;58(15):1782-93. Available from: http://doi.wiley.com/10.1002/glia.21048

44. An Intravenous Infusion Study of rHIgM22 in Patients With Multiple Sclerosis. Clinical Trials Identifier: NCT01803867 [Internet]. [cited 2019 Mar 14]. Available from: https://clinicaltrials.gov/ct2/show/NCT01803867

45. An Intravenous Infusion Study of rHIgM22 in Patients With Multiple Sclerosis Immediately Following a Relapse. ClinicalTrials.gov Identifier: NCT02398461 [Internet]. [cited 2019 Mar 14]. Available from: https://clinicaltrials.gov/ct2/show/ NCT02398461

46. Wootla B, Denic A, Watzlawik JO, Warrington AE, Rodriguez M. A single dose of a neuron-binding human monoclonal antibody improves brainstem NAA concentrations, a biomarker for density of spinal cord axons, in a model of progressive multiple sclerosis. J Neuroinflammation [Internet]. 2015;12(1):83. Available from: http://www.jneuroinflammation. com/content/12/1/83

47. Cho YK, Kim G, Park S, Sim JH, Won YJ, Hwang CH, et al. Erythropoietin promotes oligodendrogenesis and myelin repair following lysolecithin-induced injury in spinal cord slice culture. Biochem Biophys Res Commun [Internet]. 2012;417(2):753-9. Available from: https://linkinghub.elsevier.com/retrieve/pii/S0006291X11022388

48. Gyetvai G, Hughes T, Wedmore F, Roe C, Heikal L, Ghezzi P, et al. Erythropoietin Increases Myelination in Oligodendrocytes: Gene Expression Profiling Reveals Early Induction of Genes Involved in Lipid Transport and Metabolism. Front Immunol [Internet]. 2017;8. Available from: http://journal.frontiersin.org/article/10.3389/fimmu.2017.01394/full

49. Ehrenreich H, Fischer B, Norra C, Schellenberger F, Stender N, Stiefel M, et al. Exploring recombinant human erythropoietin in chronic progressive multiple sclerosis. Brain [Internet]. 2007 Oct;130(10):2577-88. Available from: https:// academic.oup.com/brain/article-lookup/doi/10.1093/brain/awm203

50. Schreiber K, Magyari M, Sellebjerg F, Iversen P, Garde E, Madsen CG, et al. High-dose erythropoietin in patients with progressive multiple sclerosis: a randomized, placebo-controlled, phase 2 trial. Mult Scler J. 2017;23(5):675-85.

51. Mameli G, Madeddu G, Mei A, Uleri E, Poddighe L, Delogu LG, et al. Activation of MSRV-type endogenous retroviruses during infectious mononucleosis and Epstein-Barr virus latency: the missing link with multiple sclerosis? PLoS One [Internet]. 2013 Nov 13;8(11):e78474-e78474. Available from: http://search.ebscohost.com/login.aspx?direct=true\&db=md$c \& A N=24236019$ \&lang $=p \mid \&$ site $=e d s-l i v e$

52. Dolei A. The aliens inside us: HERV-W endogenous retroviruses and multiple sclerosis. Mult Scler J [Internet]. 2018;24(1):42-7. Available from: http://journals.sagepub.com/doi/10.1177/1352458517737370

53. Clinical Trial Assessing the HERV-W Env Antagonist GNbAC1 for Efficacy in MS (CHANGE-MS). Clinical Trials.gov Identifier: NCT02782858 [Internet]. [cited 2019 May 27]. Available from: https://clinicaltrials.gov/ct2/show/NCT02782858

54. Daniel Kantor, MD. Update on CHANGE-MS: Clinical Trial Results for GNbAC1.Is the cause of MS within us?[Internet]. Practical Neurology. 2018 june [cited 2019 Mar 14]. Available from: https://practicalneurology.com/articles/2018-june/ update-on-change-ms-clinical-trial-results-for-gnbac1

55. Curtin F, Perron H, Kromminga A, Porchet H, Lang AB. Preclinical and early clinical development of GNbAC1, a humanized IgG4 monoclonal antibody targeting endogenous retroviral MSRV-Env protein. MAbs [Internet]. 2015;7(1):265-75. Available from: http://www.tandfonline.com/doi/full/10.4161/19420862.2014.985021

56. Domperidone in Secondary Progressive Multiple Sclerosis (SPMS). ClinicalTrials.gov Identifier: NCT02308137 [Internet]. Available from: https://clinicaltrials.gov/ct2/show/NCT02308137

57. Zhornitsky S, Yong VW, Weiss S, Metz LM. Prolactin in multiple sclerosis. Mult Scler J [Internet]. 2013;19(1):15-23. Available from: http://journals.sagepub.com/doi/10.1177/1352458512458555

58. Zhornitsky S, Johnson TA, Metz LM, Weiss S, Yong V. Prolactin in combination with interferon- $\beta$ reduces disease severity in an animal model of multiple sclerosis. J Neuroinflammation [Internet]. 2015;12(1):55. Available from: http://www. ineuroinflammation.com/content/12/1/55

59. Laurenti L, Innocenti I, Autore F, Sica S, Efremov DG. New developments in the management of chronic lymphocytic leukemia: role of ofatumumab. Onco Targets Ther [Internet]. 2016;9:421-9. Available from: https://www.dovepress.com/ new-developments-in-the-management-of-chronic-lymphocytic-leukemia-rol-peer-reviewed-article-OTT

60. Quattrocchi E, Østergaard M, Taylor PC, van Vollenhoven RF, Chu M, Mallett S, et al. Safety of Repeated Open-Label Treatment Courses of Intravenous Ofatumumab, a Human Anti-CD20 Monoclonal Antibody, in Rheumatoid Arthritis: Results from Three Clinical Trials. Chopra A, editor. PLoS One [Internet]. 2016;11(6):e0157961. Available from: https://dx.plos. org/10.1371/journal.pone.0157961 
61. Sorensen PS, Lisby S, Grove R, Derosier F, Shackelford S, Havrdova E, et al. Safety and efficacy of ofatumumab in relapsing-remitting multiple sclerosis: A phase 2 study. Neurology [Internet]. 2014;82(7):573-81. Available from: http://www. neurology.org/cgi/doi/10.1212/WNL.0000000000000125

62. Bar-Or A, Grove RA, Austin DJ, Tolson JM, VanMeter SA, Lewis EW, et al. Subcutaneous ofatumumab in patients with relapsing-remitting multiple sclerosis. Neurology [Internet]. 2018;90(20):e1805-14. Available from: http://www.neurology.org/lookup/doi/10.1212/WNL.0000000000005516

63. Agius MA, Klodowska-Duda G, Maciejowski M, Potemkowski A, Li J, Patra K, et al. Safety and tolerability of inebilizumab (MEDI-551), an anti-CD19 monoclonal antibody, in patients with relapsing forms of multiple sclerosis: Results from a phase 1 randomised, placebo-controlled, escalating intravenous and subcutaneous dose study. Mult Scler J [Internet]. 2019;25(2):235-45. Available from: http://journals.sagepub.com/doi/10.1177/1352458517740641

64. Silk M, Nantz E. Efficacy and Safety of Tabalumab in Patients with Relapsing-Remitting Multiple Sclerosis: A Randomized, Double-Blind, Placebo-Controlled Study (P3.397). Neurology [Internet]. 2018;90(15 Supplement):P3.397. Available from: http://n.neurology.org/content/90/15 Supplement/P3.397.abstract

65. Kolbinger F, Huppertz C, Mir A, Padova F. IL-17A and Multiple Sclerosis: Signaling Pathways, Producing Cells and Target Cells in the Central Nervous System. Curr Drug Targets [Internet]. 2016;17(16):1882-93. Available from: http://www. eurekaselect.com/openurl/content. php?genre=article\&issn=1389-4501\&volume=17\&issue=16\&spage=1882

66. Cingoz O. Ustekinumab. MAbs [Internet]. 2009;1(3):216-21. Available from: http://www.ncbi.nlm.nih.gov/pubmed/20069753

67. Hart BA t., Brok HPM, Remarque E, Benson J, Treacy G, Amor S, et al. Suppression of Ongoing Disease in a Nonhuman Primate Model of Multiple Sclerosis by a Human-Anti-Human IL-12p40 Antibody. J Immunol [Internet]. 2005;175(7):47618. Available from: http://www.jimmunol.org/cgi/doi/10.4049/iimmunol.175.7.4761

68. Brok HPM, van Meurs M, Blezer E, Schantz A, Peritt D, Treacy G, et al. Prevention of Experimental Autoimmune Encephalomyelitis in Common Marmosets Using an Anti-IL-12p40 Monoclonal Antibody. J Immunol [Internet]. 2002;169(11):655463. Available from: http://www.jimmunol.org/cgi/doi/10.4049/jimmunol.169.11.6554

69. Segal BM, Constantinescu CS, Raychaudhuri A, Kim L, Fidelus-Gort R, Kasper LH. Repeated subcutaneous injections of IL12/23 p40 neutralising antibody, ustekinumab, in patients with relapsing-remitting multiple sclerosis: a phase II, double-blind, placebo-controlled, randomised, dose-ranging study. Lancet Neurol [Internet]. 2008;7(9):796-804. Available from: https://linkinghub.elsevier.com/retrieve/pii/S147444220870173X

70. Longbrake EE, Racke MK. Why did IL-12/IL-23 antibody therapy fail in multiple sclerosis? Expert Rev Neurother [Internet]. 2009;9(3):319-21. Available from: http://www.tandfonline.com/doi/full/10.1586/14737175.9.3.319

71. Havrdová E, Belova A, Goloborodko A, Tisserant A, Wright A, Wallstroem E, et al. Activity of secukinumab, an antiIL-17A antibody, on brain lesions in RRMS: results from a randomized, proof-of-concept study. J Neurol [Internet]. 2016;263(7):1287-95. Available from: http://link.springer.com/10.1007/s00415-016-8128-x

72. Serada S, Fujimoto M, Mihara M, Koike N, Ohsugi Y, Nomura S, et al. IL-6 blockade inhibits the induction of myelin antigen-specific Th17 cells and Th1 cells in experimental autoimmune encephalomyelitis. Proc Natl Acad Sci [Internet]. 2008;105(26):9041-6. Available from: http://www.pnas.org/lookup/doi/10.1073/pnas.0802218105

73. Beauchemin P, Carruthers R. MS arising during Tocilizumab therapy for rheumatoid arthritis. Mult Scler J [Internet]. 2016;22(2):254-6. Available from: http://journals.sagepub.com/doi/10.1177/1352458515623862

74. Codarri L, Gyülvészi G, Tosevski V, Hesske L, Fontana A, Magnenat L, et al. RORyt drives production of the cytokine GMCSF in helper T cells, which is essential for the effector phase of autoimmune neuroinflammation. Nat Immunol [Internet]. 2011;12(6):560-7. Available from: http://www.nature.com/articles/ni.2027

75. Li R, Rezk A, Miyazaki Y, Hilgenberg E, Touil H, Shen P, et al. Proinflammatory GM-CSF-producing B cells in multiple sclerosis and B cell depletion therapy. Sci Transl Med [Internet]. 2015;7(310):310ra166-310ra166. Available from: http://stm. sciencemag.org/lookup/doi/10.1126/scitrans/med.aab4176

76. Constantinescu CS, Asher A, Fryze W, Kozubski W, Wagner F, Aram J, et al. Randomized phase 1b trial of MOR103, a human antibody to GM-CSF, in multiple sclerosis. Neurol - Neuroimmunol Neuroinflammation [Internet]. 2015;2(4):e117. Available from: http://nn.neurology.org/lookup/doi/10.1212/NXI.0000000000000117

77. Waxman SG. Mechanisms of Disease: sodium channels and neuroprotection in multiple sclerosis-current status. Nat Clin Pract Neurol [Internet]. 2008;4(3):159-69. Available from: http://www.nature.com/articles/ncpneuro0735

78. Dutta R, Trapp BD. Mechanisms of neuronal dysfunction and degeneration in multiple sclerosis. Prog Neurobiol [Internet]. 2011;93(1):1-12. Available from: https://linkinghub.elsevier.com/retrieve/pii/S030100821000170X

79. Kapoor R, Furby J, Hayton T, Smith KJ, Altmann DR, Brenner R, et al. Lamotrigine for neuroprotection in secondary progressive multiple sclerosis: a randomised, double-blind, placebo-controlled, parallel-group trial. Lancet Neurol [Internet]. 2010;9(7):681-8. Available from: https://linkinghub.elsevier.com/retrieve/pii/S1474442210701319 
80. Gnanapavan S, Grant D, Morant S, Furby J, Hayton T, Teunissen CE, et al. Biomarker Report from the Phase II Lamotrigine Trial in Secondary Progressive MS - Neurofilament as a Surrogate of Disease Progression. Derfuss T, editor. PLoS One [Internet]. 2013;8(8):e70019. Available from: https://dx.plos.org/10.1371/journal.pone.0070019

81. Raftopoulos R, Hickman SJ, Toosy A, Sharrack B, Mallik S, Paling D, et al. Phenytoin for neuroprotection in patients with acute optic neuritis: a randomised, placebo-controlled, phase 2 trial. Lancet Neurol [Internet]. 2016;15(3):259-69. Available from: https://linkinghub.elsevier.com/retrieve/pii/S1474442216000041

82. Lidster K, Jackson SJ, Ahmed Z, Munro P, Coffey P, Giovannoni G, et al. Neuroprotection in a Novel Mouse Model of Multiple Sclerosis. Villoslada P, editor. PLoS One [Internet]. 2013;8(11):e79188. Available from: https://dx.plos.org/10.1371/ journal.pone.0079188

83. Cheah BC, Vucic S, Krishnan A V, Kiernan MC. Riluzole, neuroprotection and amyotrophic lateral sclerosis. Curr Med Chem [Internet]. 2010;17(18):1942-199. Available from: http://www.ncbi.nlm.nih.gov/pubmed/20377511

84. Connick P, De Angelis F, Parker RA, Plantone D, Doshi A, John N, et al. Multiple Sclerosis-Secondary Progressive Multi-Arm Randomisation Trial (MS-SMART): a multiarm phase Ilb randomised, double-blind, placebo-controlled clinical trial comparing the efficacy of three neuroprotective drugs in secondary progressive multiple scl. BMJ Open [Internet]. 2018;8(8):e021944. Available from: http://bmjopen.bmj.com/lookup/doi/10.1136/bmjopen-2018-021944

85. Morsali D, Bechtold D, Lee W, Chauhdry S, Palchaudhuri U, Hassoon P, et al. Safinamide and flecainide protect axons and reduce microglial activation in models of multiple sclerosis. Brain [Internet]. 2013;136(4):1067-82. Available from: https://academic.oup.com/brain/article-lookup/doi/10.1093/brain/awt041

86. McKee JB, Cottriall CL, Elston J, Epps S, Evangelou N, Gerry S, et al. Amiloride does not protect retinal nerve fibre layer thickness in optic neuritis in a phase 2 randomised controlled trial. Mult Scler J [Internet]. 2019;25(2):246-55. Available from: http://journals.sagepub.com/doi/10.1177/1352458517742979

87. Zhang F, Zhou H, Wilson BC, Shi J-S, Hong J-S, Gao H-M. Fluoxetine protects neurons against microglial activation-mediated neurotoxicity. Parkinsonism Relat Disord [Internet]. 2012;18:S213-7. Available from: https://linkinghub.elsevier.com/ retrieve/pii/S1353802011700669

88. Cambron M, Mostert J, Haentjens P, D'Hooghe M, Nagels G, Willekens B, et al. Fluoxetine in Progressive Multiple Sclerosis (FLUOX-PMS): study protocol for a randomized controlled trial. Trials [Internet]. 2014;15(1):37. Available from: https://trialsjournal.biomedcentral.com/articles/10.1186/1745-6215-15-37

89. Comi G. CONCERTO: a placebo-controlled trial of oral laquinimod in patients with relapsing-remitting multiple sclerosis [Internet]. ECTRIMS Online Library. 2017 [cited 2019 Mar 14]. Available from: concerto: a placebo-controlled trial of oral laquinimod in patients with relapsing-remitting multiple sclerosis

90. A Phase 2 Clinical Study in Subjects With Primary Progressive Multiple Sclerosis to Assess the Efficacy, Safety and Tolerability of Two Oral Doses of Laquinimod Either of $0.6 \mathrm{mg} /$ Day or $1.5 \mathrm{mg} /$ Day (Experimental Drug) as Compared to Placebo. ClinicalTrials.g [Internet]. [cited 2019 Mar 14]. Available from: https://clinicaltrials.gov/ct2/show/NCT02284568

91. Mishra MK, Wang J, Keough MB, Fan Y, Silva C, Sloka S, et al. Laquinimod reduces neuroaxonal injury through inhibiting microglial activation. Ann Clin Transl Neurol [Internet]. 2014;1(6):409-22. Available from: http://doi.wiley.com/10.1002/ acn3.67

92. Wilmes AT, Reinehr S, Kühn S, Pedreiturria X, Petrikowski L, Faissner S, et al. Laquinimod protects the optic nerve and retina in an experimental autoimmune encephalomyelitis model. J Neuroinflammation [Internet]. 2018;15(1):183. Available from: https://ineuroinflammation.biomedcentral.com/articles/10.1186/s12974-018-1208-3

93. Gentile A, Musella A, De Vito F, Fresegna D, Bullitta S, Rizzo FR, et al. Laquinimod ameliorates excitotoxic damage by regulating glutamate re-uptake. J Neuroinflammation [Internet]. 2018;15(1):5. Available from: https://jneuroinflammation. biomedcentral.com/articles/10.1186/s12974-017-1048-6

94. Tikka TM, Koistinaho JE. Minocycline Provides Neuroprotection Against N-Methyl-D-aspartate Neurotoxicity by Inhibiting Microglia. J Immunol [Internet]. 2001;166(12):7527-33. Available from: http://www.jimmunol.org/cgi/doi/10.4049/ jimmunol.166.12.7527

95. Yang Y, Salayandia VM, Thompson JF, Yang LY, Estrada EY, Yang Y. Attenuation of acute stroke injury in rat brain by minocycline promotes blood-brain barrier remodeling and alternative microglia/macrophage activation during recovery. J Neuroinflammation [Internet]. 2015;12(1):26. Available from: http://www.jneuroinflammation.com/content/12/1/26

96. Metz LM, Li DKB, Traboulsee AL, Duquette P, Eliasziw M, Cerchiaro G, et al. Trial of Minocycline in a Clinically Isolated Syndrome of Multiple Sclerosis. N Engl J Med [Internet]. 2017 Jun;376(22):2122-33. Available from: http://www.jneuroinflammation.com/content/12/1/26

97. Cho Y, Crichlow G V., Vermeire JJ, Leng L, Du X, Hodsdon ME, et al. Allosteric inhibition of macrophage migration inhibitory factor revealed by ibudilast. Proc Natl Acad Sci [Internet]. 2010;107(25):11313-8. Available from: http://www.pnas. org/cgi/doi/10.1073/pnas.1002716107 
98. Mizuno T, Kurotani T, Komatsu Y, Kawanokuchi J, Kato H, Mitsuma N, et al. Neuroprotective role of phosphodiesterase inhibitor ibudilast on neuronal cell death induced by activated microglia. Neuropharmacology [Internet]. 2004;46(3):40411. Available from: https://linkinghub.elsevier.com/retrieve/pii/S0028390803003721

99. Fox RJ, Coffey CS, Conwit R, Cudkowicz ME, Gleason T, Goodman A, et al. Phase 2 Trial of Ibudilast in Progressive Multiple Sclerosis. N Engl J Med [Internet]. 2018 Aug 30;379(9):846-55. Available from: http://www.nejm.org/doi/10.1056/ NEJMoa1803583

100. Su KG, Banker G, Bourdette D, Forte M. Axonal degeneration in multiple sclerosis: the mitochondrial hypothesis. Curr Neurol Neurosci Rep [Internet]. 2009;9(5):411-7. Available from: http://www.ncbi.nlm.nih.gov/pubmed/19664372

101. Dutta R, McDonough J, Yin X, Peterson J, Chang A, Torres T, et al. Mitochondrial dysfunction as a cause of axonal degeneration in multiple sclerosis patients. Ann Neurol [Internet]. 2006;59(3):478-89. Available from: http://doi.wiley. com/10.1002/ana.20736

102. Campbell GR, Ziabreva I, Reeve AK, Krishnan KJ, Reynolds R, Howell O, et al. Mitochondrial DNA deletions and neurodegeneration in multiple sclerosis. Ann Neurol [Internet]. 2011;69(3):481-92. Available from: http://doi.wiley. com/10.1002/ana.22109

103. Sedel F, Bernard D, Mock DM, Tourbah A. Targeting demyelination and virtual hypoxia with high-dose biotin as a treatment for progressive multiple sclerosis. Neuropharmacology [Internet]. 2016;110:644-53. Available from: https://linkinghub.elsevier.com/retrieve/pii/S0028390815300733

104. Tourbah A, Lebrun-Frenay C, Edan G, Clanet M, Papeix C, Vukusic S, et al. MD1003 (high-dose biotin) for the treatment of progressive multiple sclerosis: A randomised, double-blind, placebo-controlled study. Mult Scler J [Internet]. 2016;22(13):1719-31. Available from: http://journals.sagepub.com/doi/10.1177/1352458516667568

105. Tourbah A, Gout O, Vighetto A, Deburghgraeve V, Pelletier J, Papeix C, et al. MD1003 (High-Dose Pharmaceutical-Grade Biotin) for the Treatment of Chronic Visual Loss Related to Optic Neuritis in Multiple Sclerosis: A Randomized, Double-Blind, Placebo-Controlled Study. CNS Drugs [Internet]. 2018;32(7):661-72. Available from: http://journals.sagepub.com/doi/10.1177/1352458516667568

106. Yu-Wai-Man P, Soiferman D, Moore DG, Burté F, Saada A. Evaluating the therapeutic potential of idebenone and related quinone analogues in Leber hereditary optic neuropathy. Mitochondrion [Internet]. 2017;36:36-42. Available from: https://linkinghub.elsevier.com/retrieve/pii/S1567724917300120

107. Kearney M, Orrell RW, Fahey M, Brassington R, Pandolfo M. Pharmacological treatments for Friedreich ataxia [Internet]. Cochrane Database of Systematic Reviews. 2016 [cited 2019 Mar 14]. Available from: http://doi.wiley. com/10.1002/14651858.CD007791.pub4

108. Parkinson MH, Schulz JB, Giunti P. Co-enzyme $Q 10$ and idebenone use in Friedreich's ataxia. J Neurochem [Internet]. 2013;126:125-41. Available from: http://doi.wiley.com/10.1111/jnc.12322

109. Idebenone for Primary Progressive Multiple Sclerosis. ClinicalTrials.gov Identifier: NCT01854359 [Internet]. [cited 2019 Mar 14]. Available from: https://clinicaltrials.gov/ct2/show/NCT01854359

110. Mao P, Manczak M, Shirendeb UP, Reddy PH. MitoQ, a mitochondria-targeted antioxidant, delays disease progression and alleviates pathogenesis in an experimental autoimmune encephalomyelitis mouse model of multiple sclerosis. Biochim Biophys Acta - Mol Basis Dis [Internet]. 2013;1832(12):2322-31. Available from: https://linkinghub.elsevier. com/retrieve/pii/S0925443913002846

111. Biewenga GP, Haenen GRMM, Bast A. The pharmacology of the antioxidant lipoic acid. Gen Pharmacol Vasc Syst [Internet]. 1997;29(3):315-31. Available from: https://linkinghub.elsevier.com/retrieve/pii/s0306362396004740

112. Yadav V, Marracci G, Lovera J, Woodward W, Bogardus K, Marquardt W, et al. Lipoic acid in multiple sclerosis: a pilot study. Mult Scler J [Internet]. 2005 Apr 2;11(2):159-65. Available from: http://journals.sagepub.com/ doi/10.1191/1352458505ms1143oa

113. Spain R, Powers K, Murchison C, Heriza E, Winges K, Yadav V, et al. Lipoic acid in secondary progressive MS. Neurol - Neuroimmunol Neuroinflammation [Internet]. 2017;4(5):e374. Available from: http://nn.neurology.org/lookup/ doi/10.1212/NXI.0000000000000374

114. Danesh FR, Anel RL, Zeng L, Lomasney J, Sahai A, Kanwar YS. Immunomodulatory effects of HMG-CoA reductase inhibitors. Arch Immunol Ther Exp (Warsz) [Internet]. 2003;51(3):139-48. Available from: http://www.ncbi.nlm.nih.gov/ pubmed/12894868

115. Chan D, Binks S, Nicholas JM, Frost C, Cardoso MJ, Ourselin S, et al. Effect of high-dose simvastatin on cognitive, neuropsychiatric, and health-related quality-of-life measures in secondary progressive multiple sclerosis: secondary analyses from the MS-STAT randomised, placebo-controlled trial. Lancet Neurol [Internet]. 2017;16(8):591-600. Available from: https://linkinghub.elsevier.com/retrieve/pii/S1474442217301138 
116. Chataway J, Schuerer N, Alsanousi A, Chan D, MacManus D, Hunter K, et al. Effect of high-dose simvastatin on brain atrophy and disability in secondary progressive multiple sclerosis (MS-STAT): a randomised, placebo-controlled, phase 2 trial. Lancet [Internet]. 2014;383(9936):2213-21. Available from: https://linkinghub.elsevier.com/retrieve/pii/ $\underline{\text { S0140673613622424 }}$

117. Sohn H-M, Hwang J-Y, Ryu J-H, Kim J, Park S, Park J, et al. Simvastatin protects ischemic spinal cord injury from cell death and cytotoxicity through decreasing oxidative stress: in vitro primary cultured rat spinal cord model under oxygen and glucose deprivation-reoxygenation conditions. J Orthop Surg Res [Internet]. 2017;12(1):36. Available from: http://josr-online.biomedcentral.com/articles/10.1186/s13018-017-0536-9

118. van der Most PJ, Dolga AM, Nijholt IM, Luiten PGM, Eisel ULM. Statins: Mechanisms of neuroprotection. Prog Neurobiol [Internet]. 2009;88(1):64-75. Available from: https://linkinghub.elsevier.com/retrieve/pii/S0301008209000318

119. Kappos L, Bar-Or A, Cree BAC, Fox RJ, Giovannoni G, Gold R, et al. Siponimod versus placebo in secondary progressive multiple sclerosis (EXPAND): a double-blind, randomised, phase 3 study. Lancet [Internet]. 2018;391(10127):1263-73. Available from: https://linkinghub.elsevier.com/retrieve/pii/S0140673618304756

120. Gajofatto A. Spotlight on siponimod and its potential in the treatment of secondary progressive multiple sclerosis: the evidence to date. Drug Des Devel Ther [Internet]. 2017;Volume 11:3153-7. Available from: https://www.dovepress. com/spotlight-on-siponimod-and-its-potential-in-the-treatment-of-secondary-peer-reviewed-article-DDDT

121. Jope RS, Yuskaitis CJ, Beurel E. Glycogen Synthase Kinase-3 (GSK3): Inflammation, Diseases, and Therapeutics. Neurochem Res [Internet]. 2007;32(4-5):577-95. Available from: http://link.springer.com/10.1007/s11064-006-9128-5

122. De Sarno P, Axtell RC, Raman C, Roth KA, Alessi DR, Jope RS. Lithium Prevents and Ameliorates Experimental Auto immune Encephalomyelitis. J Immunol [Internet]. 2008;181(1):338-45. Available from: http://www.jimmunol.org/cgi/ doi/10.4049/iimmunol.181.1.338

123. Rinker J., Meador W, Sung V, Nicholas A, Cutter G. Results of a pilot trial of lithium in progressive multiple sclerosis [Internet]. ECTRIMS Online Library. [cited 2019 Mar 14]. Available from: https://onlinelibrary.ectrims-congress.eu/ectrims/2016/32nd/145965/john.rinker.ii.results.of.a.pilot.trial.of.lithium.in.progressive.multiple.html

124. Chu F, Shi M, Lang Y, Shen D, Jin T, Zhu J, et al. Gut Microbiota in Multiple Sclerosis and Experimental Autoimmune Encephalomyelitis: Current Applications and Future Perspectives. Mediators Inflamm [Internet]. 2018;2018:1-17. Available from: https://www.hindawi.com/journals/mi/2018/8168717/

125. Islas Weinstein L, Revuelta A, Pando RH. Catecholamines and acetylcholine are key regulators of the interaction between microbes and the immune system. Ann N Y Acad Sci [Internet]. 2015;1351(1):39-51. Available from: http:// doi.wiley.com/10.1111/nyas.12792

126. Kim Y-K, Shin C. The Microbiota-Gut-Brain Axis in Neuropsychiatric Disorders: Pathophysiological Mechanisms and Novel Treatments. Curr Neuropharmacol [Internet]. 2018;16(5):559-73. Available from: http://www.eurekaselect. com/155613/article

127. Ochoa-Repáraz J, Mielcarz DW, Haque-Begum S, Kasper LH. Induction of a regulatory B cell population in experimental allergic encephalomyelitis by alteration of the gut commensal microflora. Gut Microbes [Internet]. 2010 Mar 4;1(2):103-8. Available from: http://www.tandfonline.com/doi/abs/10.4161/gmic.1.2.11515

128. Wang Y, Begum-Haque S, Telesford KM, Ochoa-Repáraz J, Christy M, Kasper EJ, et al. A commensal bacterial product elicits and modulates migratory capacity of CD39 + CD4 T regulatory subsets in the suppression of neuroinflammation. Gut Microbes [Internet]. 2014;5(4):552-61. Available from: http://www.tandfonline.com/doi/abs/10.4161/gmic.29797

129. Lee YK, Menezes JS, Umesaki Y, Mazmanian SK. Proinflammatory T-cell responses to gut microbiota promote experimental autoimmune encephalomyelitis. Proc Natl Acad Sci [Internet]. 2011;108(Supplement 1):4615-22. Available from: http://www.pnas.org/cgi/doi/10.1073/pnas.1000082107

130. Berer K, Gerdes LA, Cekanaviciute E, Jia X, Xiao L, Xia Z, et al. Gut microbiota from multiple sclerosis patients enables spontaneous autoimmune encephalomyelitis in mice. Proc Natl Acad Sci [Internet]. 2017;114(40):10719-24. Available from: http://www.pnas.org/lookup/doi/10.1073/pnas.1711233114

131. Chen J, Chia N, Kalari KR, Yao JZ, Novotna M, Paz Soldan MM, et al. Multiple sclerosis patients have a distinct gut microbiota compared to healthy controls. Sci Rep [Internet]. 2016;6(1):28484. Available from: http://www.nature.com/ articles/srep28484

132. Kwon H-K, Kim G-C, Kim Y, Hwang W, Jash A, Sahoo A, et al. Amelioration of experimental autoimmune encephalomyelitis by probiotic mixture is mediated by a shift in Thelper cell immune response. Clin Immunol [Internet]. 2013;146(3):21727. Available from: https://linkinghub.elsevier.com/retrieve/pii/S1521661613000028

133. Kouchaki E, Tamtaji OR, Salami M, Bahmani F, Daneshvar Kakhaki R, Akbari E, et al. Clinical and metabolic response to probiotic supplementation in patients with multiple sclerosis: A randomized, double-blind, placebo-controlled trial. Clin Nutr [Internet]. 2017;36(5):1245-9. Available from: https://linkinghub.elsevier.com/retrieve/pii/S026156141630214X 
134. Makkawi S, Camara-Lemarroy C, Metz L. Fecal microbiota transplantation associated with 10 years of stability in a patient with SPMS. Neurol - Neuroimmunol Neuroinflammation [Internet]. 2018;5(4):e459. Available from: http:// nn.neurology.org/lookup/doi/10.1212/NXI.0000000000000459

135. Fecal Microbial Transplantation in Relapsing Multiple Sclerosis Patients. ClinicalTrials.gov Identifier: NCT03183869 [Internet]. [cited 2019 Mar 14]. Available from: https://clinicaltrials.gov/ct2/show/NCT03183869

136. Correale J, Farez MF. The impact of parasite infections on the course of multiple sclerosis. J Neuroimmunol [Internet]. 2011;233(1-2):6-11. Available from: https://linkinghub.elsevier.com/retrieve/pii/S0165572811000051

137. Dixit A, Tanaka A, Greer JM, Donnelly S. Novel Therapeutics for Multiple Sclerosis Designed by Parasitic Worms. Int J Mol Sci [Internet]. 2017;18(10):2141. Available from: http://www.mdpi.com/1422-0067/18/10/2141

138. Terrazas C, de Dios Ruiz-Rosado J, Amici SA, Jablonski KA, Martinez-Saucedo D, Webb LM, et al. Helminth-induced Ly6Chi monocyte-derived alternatively activated macrophages suppress experimental autoimmune encephalomyelitis. Sci Rep [Internet]. 2017;7(1):40814. Available from: http://www.nature.com/articles/srep40814 